J OURNAL OF French and Francophone Philosophy
REV VE DE L A

philosophie française et de langue française

\title{
The World is One Great Hospital
}

\section{David-Olivier Gougelet}

Journal of French and Francophone Philosophy - Revue de la philosophie française et de langue française, Vol XVIII, No 1 (2008-2010) pp. 43-66.

\author{
Vol XVIII, No 1 (2008-2010) \\ ISSN 1936-6280 (print) \\ ISSN 2155-1162 (online) \\ DOI 10.5195/jffp.2010.168 \\ http: / / www.jffp.org
}

\section{(c) EY-NC-ND}

This work is licensed under a Creative Commons Attribution-Noncommercial-No Derivative Works 3.0 United States License.

\section{ULIS D-Sunt}

This journal is operated by the University Library System of the University of Pittsburgh as part of its D-Scribe Digital Publishing Program, and is co-sponsored by the University of Pittsburgh Press 


\section{The World is One Great Hospital}

\section{David-Olivier Gougelet}

American University

\section{Introduction}

This article attempts to locate the origin of Foucault's work on biopolitics and biopower in his writings on medicine and medicalization. Though the concept of biopower is in Foucault's published work most closely associated with his genealogy of the dispositif of sexuality, ${ }^{1}$ this essay will set aside the question of sexuality and examine more closely the archeology and genealogy of the medical setup to which Foucault dedicated a significant portion of his work throughout the $60^{\prime}$ s and $70^{\prime}$ s, in order to find therein the lineage of his thought on biopower and biopolitics. As Guillaume le Blanc proposes, "the medicalization of human life is the major event in biopolitics," for it reveals that "the history of man merges more and more with the history of life, such that vital phenomena are increasingly determinant in the understanding of human life." ${ }^{2}$ Now, Foucault appears, in the first volume of his History of Sexuality, to relegate, at least on the surface, this medicalization of life to a secondary position in relation to the setup of sexuality, a setup he believes to be central to the emergence during the $18^{\text {th }}$ century of a power he will call in the final chapter of that work "biopower." 3 And yet this article will attempt to show that if one desires to find the trace of this novel form of power in Foucault's work prior to March $17^{\text {th }}, 1976$, the date when, during a lecture at the Collège de France, he introduced for the first time the concept of biopower, ${ }^{4}$ one should look precisely to Foucault's work on medicine. In particular, we will look in this essay at the 1963 edition and 1972 re-edition of Birth of the Clinic, as well as a series of lectures on medical power Foucault gave in Brazil in 1974, all of which set the stage, whether directly or indirectly, for the work on biopower that was to follow.

As we have already seen, it is in 1976, in the final chapter of the first volume of his History of Sexuality, that Foucault introduced for the first time in his published writings this novel object of analysis that he would come to call "biopower." Now, when one compares Foucault's description of biopower in The Will to Knowledge to that of disciplinary power he had 
provided the previous year in Discipline and Punish, one can immediately see that this new object of analysis is both more vast and more complex than the disciplinary power on which Foucault had heretofore concentrated, not only in his published writings, but also at the Collège de France, in the lectures he had given there throughout the early 1970's. Indeed, in "Right of Death and Power Over Life," Foucault appears to complicate his own genealogy of power: where he had already demonstrated in Discipline and Punish that the West had, during the classical epoch, known a profound transformation in the regime of power operating within its societies, not only in its punitive systems, but throughout those societies, he shows in The Will to Knowledge that this transformation was not only that of a sovereign power into a disciplinary power, but that the classical epoch should also be seen as marking the emergence of an entirely novel regime of power, specifically, of a power "situated and exercised at the level of life, of the species, of the race, and of the large-scale phenomena of population." ${ }^{5}$ Thus, according to Foucault, what is at stake in this novel modality of power is no longer the juridical existence of sovereignty, but the biological existence of a population: beginning in the $18^{\text {th }}$ and $19^{\text {th }}$ centuries, one can see the emergence of a regime of power whose mechanisms have as their function no longer solely that of exaction [prélèvement] (of time, goods, and so on), but also the incitation, reinforcement, control, monitoring, maximization, and organization of the forces upon which they intervene. In other words, the regime of biopower that appears at this time is a power "that exerts itself positively on life, that endeavors to administer it, to increase it, to maximize it, to multiply it, to exercise over it precise controls and large-scale regulations." ${ }^{6}$ From a regime of power in which the sovereign reserved for himself or herself the right to kill or to let live, we therefore transition to a regime of power that will put in play the biological imperative of "making live" [faire vivre], while reserving the right to "discard into death" [rejeter dans la mort] those who would threaten, by virtue of the biological danger they bear within them, the well-being and health of the population and, through it, the survival of the State.

Accordingly, the regime of power Foucault describes in "Right of Death and Power Over Life" is a power for which the point of intervention is no longer the juridical subject, nor even solely the somatic singularity discussed in Discipline and Punish, but a population of living beings, beings whose biological existence must henceforth be taken charge of and controlled through a number of setups, chief amongst which, for Foucault, appears to be that of sexuality. Along with "biohistory," understood as the pressures through which the processes of life and of history interfere with one another, we must consequently analyze the emergence of something like a "biopolitics," understood in this context as that which introduces life and its mechanisms into the domain of "explicit calculations" and makes of power and knowledge "agents of transformation" of human life. ${ }^{7}$ 
Now, concretely, and it is this affirmation on the part of Foucault that will serve as the starting point for our analysis, this biopolitics, this "power over life," took two principal forms: 1) a technology/politics of the individual human body concerned with controlling and taming the forces of the body through the application of disciplinary mechanisms, and 2) a technology/politics of the population concerned with the regulation of processes proper to a mass of living beings, such as birth and mortality rates, lifespan, health and medical practices, and so on. ${ }^{8}$ Far from conflicting with, or even mutually excluding, one another, these two modalities intersect, constantly supporting and reinforcing each other. Thus, if disciplinary power consists of those mechanisms and tactics whose operation produces a docile body and a normalized subject, then biopolitics concerns itself with addressing problems of mass and with regulating the life of a population: as Foucault would explain in his 1977 Security, Territory, Population lecture course, the failure of sovereign and disciplinary mechanisms of power to deal with increasingly destabilizing problems of mass (problem-events such as famines, epidemics, and the like, as well as problematic spaces like the city) necessitated the elaboration of a novel biopolitical setup, one that took the population, and its myriad phenomena, as its point of intervention. ${ }^{9}$ Within this novel modality of power, the disciplines would continue to play a crucial role, insofar as biopower's interventions upon the population resulted in a new understanding of the relation between the collective and the individuals that taken together composed the social body; in the context of the relevance of governmental action, many new measures of government were intended to have mass effects upon the population, such that the level of the multiplicity of individuals became more of a relay for these collective effects.

At the heart of Foucault's work on biopower, then, lies the population, as well as the question of how novel mechanisms and technologies were elaborated in order to ensure its health and well-being. As Foucault notes early in The Will to Knowledge, the $18^{\text {th }}$ century saw the emergence of one of the great innovations of the nascent regime of biopower, namely, the constitution of the population as an "economic and political problem," and consequently as an object of intervention. ${ }^{10}$ During that time, modern European states began to conceive of themselves as having to govern not only subjects, nor only a people, but entire populations, that is, populations as a form of wealth, populations as a resource, populations as possessing productive forces to be harnessed and put to use, and populations as multiplicities composed of living and dying organisms and exhibiting processes and phenomena proper to such a group, such as, for instance, birth and death rates, life expectancy, state of health, as well as behaviors bearing directly upon the population's well-being. Accordingly, the population, as well as its vital processes and phenomena, represented one of the points of intersection at which the "movements proper to life and the effects particular to institutions" met. ${ }^{11}$ Thus, states, for the first time, 
affirmed that their future and destiny were inextricably tied not only to the number of citizens at their disposal, for instance, but to the manner in which individuals behaved with respect to their own health, behaviors that not only affected them, but had a direct effect on the massive phenomena of the population which they made up, such as its birth and mortality rates. ${ }^{12}$ For the first time, a population's health became a matter of state concern and a domain of intervention for various discourses and mechanisms of power. As such, the question that arose within the regime of biopolitics was the following: how to intervene upon and regulate a series of phenomena (lifespan, mortality rates, birthrates, illness) that are proper to a population of living beings?

It is here, in response to this problem, that we encounter the question of the way in which the two modalities of power Foucault described in Discipline and Punish and The Will to Knowledge, namely, the disciplining of the individual and the biopolitical regulation of the health of a population, relate to one another and operate in conjunction with each other. As le Blanc rightfully notes, the emerging regime of biopolitics did not do away with the disciplines; rather, "biopower brings the disciplinary to completion" by making use of the disciplines' intervention upon the individual in order to exercise a regulatory control on the scale of the collective. ${ }^{13}$ Accordingly, we find at the heart of the question of how these two modalities of power relate to one another a triptych of interrelated setups, namely, the setups of sexuality, race, and medicalization, whereby each of them ensures, in ways that often implicate the others, the junction between disciplinary power and biopower. $^{14}$

Now, if, in this essay, we choose to focus on the setup of medicalization, its role in the biopolitical regulation of the health of the population, and its origins in his work prior to 1976, it is not because sexuality and race are secondary within Foucault's genealogy of biopower, but because medicalization, as Mauro Bertani notes, is the one setup through which a line of continuity can be established throughout the quasi-entirety of Foucault's project. Even if, in his published work, Foucault devoted only one text, Birth of the Clinic, to the explicit question of medicine, the problem of medical power and its role in the administration of life was nevertheless "determinant, not only for the life sciences in their entirety, but also for the history of the forms of truth and rationality, and ultimately for the historicalpolitical actuality itself." ${ }^{15}$ To be more specific, it is a problem we encounter as early as 1961, in History of Madness, and as late as 1984, in the very last text Foucault would publish, i.e., "Life: Experience and Science," his preface to the English translation of Canguilhem's The Normal and the Pathological. But in Foucault's work, a number of texts prove to be crucial in terms of understanding how he would arrive at his formulation in 1976 of the problematic of biopower and its relation to the population. The first of these, of course, is the aforementioned Birth of the Clinic, which Foucault 
published for the first time in 1963, and which he revised for republication in 1972, in the midst of his explicit turn, first announced in his inaugural lecture at the Collège de France, to a genealogy of the myriad mechanisms of power.

In biopower's administration of life, the medicalization of the population and the elaboration during the $18^{\text {th }}$ century of a politics of health would, along with the setups of sexuality and race, come to play central roles. Indeed, of the problems of mass these novel mechanisms of power were intended to address, the most disruptive and dangerous to the wellbeing of the social body was, along with the related problem of the city, the problem of mass illness. We will therefore focus here on the phenomenon of illness and discuss that operation of biopower that in the $18^{\text {th }}$ century resulted in the widespread medicalization of the population. Foucault would not explicitly introduce within his project the concept of biopower until much later, of course, but by that time, he had already done a significant amount of work on the question of the medicalization of the population. Thus, we will begin by looking at his discussion of the medicine of epidemics in Birth of the Clinic, ${ }^{16}$ and subsequently turn to a series of lectures Foucault would in the early 1970's devote entirely to an analysis of the process of medicalization that would ultimately prove essential to the operation of the modern regime of biopower.

\section{Birth of the Clinic: Toward a Social Medicine of Endemics}

To be sure, the emergence of a politics of health during the classical epoch did not occur as a response to the threat of illness alone; other factors, such as the inefficient and costly organization of society with regard to the practice of medicine, also contributed greatly to the widespread medicalization that took place during this time. Nevertheless, the changing status of illness within a society increasingly concerned with the promotion and management of the health of an entire population contributed greatly to the birth of a novel form of social medicine.

\section{A. Liberating the Medical Space}

In Birth of the Clinic, Foucault describes the way in which one of the factors that contributed most to the transition from an individualized and classificatory "medicine of species" to a centralized medicine of epidemics and endemics had to do with the singular and ambiguous position of the hospital within the practice of medicine. Concluding his description of the medicine of species that had dominated the practice of medicine in Europe into the $18^{\text {th }}$ century, Foucault notes that the hospital had come to pose a problem within both the medical and economic ordering of society. First, and at the level of medicine, rather than isolating an illness and thereby permitting it to appear to the doctor in its truth and essence, the hospital represented a space of mixture and contagion where illnesses intermingled, 
a "disordered garden" where the various "species [of illness]" were allowed to intersect, thus altering their "proper nature" and masking their singular truth. ${ }^{17}$ And second, the hospital also represented for society an economic problem: once admitted, the patient, already unable to participate in the productive activity of society, now became a drain upon that society's resources. Faced with this problematic status of the hospital within the practice of medicine of the day, the dominant medicine of species and leading economic theorists engaged in a thorough critique and questioning of the utility of the hospital in the classification and treatment of illness, on the one hand, and in the economic ordering of society, on the other.

Now, at the heart of the efforts of reform undertaken during this time, and as a forerunner of the privileged function it would come to fulfill in biopower's normalization of the social body, lay the institution of the family. As the "natural locus of life," the family was also the "natural locus of illness" and therefore that privileged space where the illness could "deploy itself in its truth." ${ }^{18}$ Indeed, where the hospital's doctor could only ever see an illness in its mixed and modified state, the person treating a patient in the home could isolate the illness and thereby ascertain its true nature.

Brought to its logical conclusion, then, this desire for a reform of the practice of medicine focused on the space of the family-itself motivated by a desire to allow an illness to manifest itself in its truth and thereafter to place it within a complete pathological taxonomy-implied a "free spatialization" devoid of any "privileged region" such as that of the hospital, a free space where illness could be allowed to follow its natural course and deploy itself in its own "essence" and truth. If medicine was to establish a knowledge and classification of illness, then illness had to be left in its "original ground [sol d'origine]" — the family-and allowed to reveal itself to the doctor. ${ }^{19}$ At the level of the practice of medicine, accordingly, such a plan had the benefit of allowing the reigning medicine of species to operate in the classificatory manner in which it was intended, while at the level of the economic problem of public assistance, the liberation of the space of illness in favor of the family and at the expense of the hospital would have the additional benefit of relieving society of its burden and place the onus of assistance upon the relatives of the afflicted. ${ }^{20}$

Consequently, and taken together, these two concerns with the structure of the hospital-raised first by the medicine of species, not by the medicine of epidemics that would follow-called for a novel way of conceiving of the role of medicine in society, as well as of the social space in which this medicine was to be practiced. Thus, as Foucault remarks, the concerns of the classificatory doctors and those of the economists intersected and called for the reorganization of the space of illness into an "open space" in which illness was to be isolated and permitted to follow its course, a "homogeneous space" that would fall under the eye of a medical gaze concerned primarily with the classification of the species of illness within the 
context of the practice of a private form of medicine applied to the patient not in his capacity as member of a population, but as a private individual. ${ }^{21}$

This attempt at the reform of the practice of medicine would not yet mark the emergence of the politics of health and social medicine that would accompany the thorough investment of the population on the part of biopower. Moreover, the attempt to isolate the essence of an illness and to classify it within a rigid taxonomy by liberating and homogenizing the space in which it appears, rather than by further restricting it to a privileged, medicalized space such as the hospital, may seem paradoxical. And yet, in its attempt to make the space of the practice of medicine an open and homogeneous one devoid of any privileged and isolated medicalized region, the medicine of species lay the foundation for what would soon take the form of the thorough and widespread medicalization of the social space as a whole. By the same token, and by taking its efforts to their logical, though contradictory, extreme, it would also lay the foundation for its own disappearance. That is, devoid of any privileged medical space, the entirety of the social space could be opened up to an investment and to medicalization. That is not to say, of course, that the hospital disappeared entirely. But in the efforts to reduce its role and importance within the practice of medicine, an entirely novel conception of the social space emerged, a conception that lent itself to the medical investment of the social body, and ultimately to the operation of biopower at the level of the population. And in this newly-medicalized, open and homogeneous space, the medicine of species would eventually vanish and give way to a medicine of epidemics, and with it to a novel concern for the health not of the private citizen, but of the population as a whole.

\section{B. The Epidemic Event}

Describing the extreme liberation of the medical space in which the logic of the medicine of species would ultimately undo itself, Foucault proposes that a "medical experience diluted in the free space" of a society organized according to the figure of the family implies, through the particular attention paid to the health of each individual, a "generalized vigilance" whose extension coincides with the "group as a whole." In other words, in order to do what it set out to do, the practice of medicine had to become a state medicine, that is, a "national task" ultimately connected to a centralized politics of health. Thus, the familial model of medicine had to rely on a structure of medicine that was "collectively controlled" and that would exert an influence over the entirety of the social space, with the end of the $18^{\text {th }}$ century thereby witnessing a definite "institutional spatialization of illness." 22 This institutionalization of illness would play an essential role in the medical investment of the population on the part of biopower. Moreover, it is a development in which the problem of epidemics would figure prominently. 
With the advent of the medicine of state, to the rise of which the efforts of the medicine of species ultimately contributed, we can already see a transition from the health of the individual to that of the collective: insofar as the "liberation" of the medical space implied a generalized vigilance over the entirety of the social space, it was only natural that the "political consciousness" of illness become concerned with the health of the social body as a whole. Later, Foucault would explicitly conceive of this transition in terms of biopower and population. In Birth of the Clinic, he would address this transition in its relation to a changing perception of illness, and of the threat of illness, within the practice of medicine.

Even as, during the end of the $18^{\text {th }}$ century, the medicine of species was following its own logic of liberation to its conclusion, the concepts of epidemic, of endemic illness, and so on, were following their own conceptual path. Each of these two medical concerns-that having to do with classificatory medicine's opening up of the social space as a medical space and that having to do with the increasing importance of the problem of epidemics-would eventually intersect within a centralized social medicine that would come to invest the social body through and through. But at first, the problem of epidemics remained separate from that of the structure of the hospital, for instance, or of the status of public assistance. As Foucault himself would state in Birth of the Clinic, the notions of "endemic illness" and "epidemic" would, during the classical epoch and with respect to the medicine of species, have a "singular destiny [destinée singulière]." ${ }^{23}$ And at the heart of this singular destiny would lie the complex, but increasingly important, relation between the concepts of "constitution," of "epidemic," and of "endemic illness."

Appearing around the end of the $17^{\text {th }}$ century in the work of figures like Thomas Sydenham and gaining subsequent prominence, the concept of the epidemic "constitution" would, according to Foucault, mark the advent of a novel "historical and geographical consciousness of illness." 24 Emerging as a new manner of conceiving of illness, the epidemic constitution referred not to an "autonomous," pure species of illness, but to a "transitory knot" of causal factors, that is, of natural phenomena tied to the appearance of such and such illness. In this way, factors that had hitherto been neglected in the consideration of mass illness-factors such as climate, quality of soil, famine, and so on-would become central to the emerging medicine of epidemics, and would set the stage for the emergence of a medicine of the collective.

In the pages of Birth of the Clinic dedicated to the problem of the epidemic and to its relation to the birth of a state medicine, Foucault shows the manner in which the concept of the epidemic constitution provided a new framework through which could be conceptualized illness in general and epidemics in particular. As the concept began to take hold over the course of the $18^{\text {th }}$ century, so too did a new conception of illness as a 
massive, rather than individual, phenomenon. That is to say, even as the concept of illness as species remained a legitimate medical concern for the time, the epidemic became a "coherent and sufficient mode" of conceiving of illness, rather than the mere "particular form" of a species of illness. The epidemic, for the emerging medicine of the collective, represented a constitution whose phenomena proved more constant and homogeneous than usual. For this reason, the proper object of a medicine of epidemics was not a "specific type" of illness, but rather a "knot" of circumstances, conditions, and causal factors: the ground of an epidemic was not a particular illness, such as the bubonic plague, but the group of environmental causes and events responsible for the appearance of a given illness at a given time and in a given place, such as the conditions in Marseille in 1721, in Rouen in 1769 , and so on. ${ }^{25}$

The question, then, was not one of classification, as it had been for the medicine of species, but one of causality. Thus, the task of the medicine of mass illness was not to identify the "general form of an illness" and then to classify it within an ordered taxonomy, but instead to ascertain beneath the "general signs of illness" the "variable" and "singular process" linking the causal knot of a massive illness to its manifest, "morbid form." If the constancy of the signs of an illness across a group of people indicated anything, it was not a "natural order," but a "constancy of causes" to be analyzed. And this analysis, in turn, could take two general forms. In some cases, the causes to be analyzed could be the type of causes linked to a morbid form of illness that seemingly appeared at random, in one place, and afflicted all people, regardless of age, sex, and so on, only to disappear as abruptly as it had appeared. As understood within the nascent medicine of massive illnesses, these morbid forms of illness were tied to a general, but accidental, that is, aleatory, causal knot and were what should properly be termed "epidemics." In other cases, meanwhile, the causes to be analyzed could be of the sort to last over time, manifesting themselves at specific times and in specific places, but never really disappearing, unlike the causes linked to epidemics. Though related to the latter, the types of morbid forms tied to these more lasting, constant causal knots nonetheless differed from them and were properly called "endemic illnesses." 26 Now, in later texts like "Society Must Be Defended," Foucault would claim that even if the biopolitics of the population that accompanied the emergence of biopower came to be concerned with both types of massive illness, the endemic illness, by virtue of the constancy of the threat it posed to the population, came to occupy a privileged position within the politics of health of the $18^{\text {th }}$ and $19^{\text {th }}$ centuries. Setting aside this distinction for the moment, however, we can see how both the problems of epidemic and endemic illnesses would become essential to an effort aimed at the protection of the population through its thorough medicalization. 
To be sure, Foucault does not, at least in Birth of the Clinic, explicitly tie the problem of massive illness to biopower. But his discussion of the nascent medicine of epidemics and endemics does provide us with some indication of the manner in which the two-the problem of massive illness on the one hand and biopower's medicalized administration of life-came to be connected within a nascent politics of health. Distinguishing massive illnesses from individual, classifiable species, Foucault explicitly characterizes endemic and epidemic illnesses in terms of the concept of an "event:" central to an epidemic constitution, and thus under any phenomenon of mass illness, is a knot of causal factors and conditions conceived of as "natural events," and which must be analyzed in relation to the morbid forms to which they give rise in a given space and at a given time. ${ }^{27}$ Moreover, within the domain of life, classical medicine conceived of an epidemic or endemic event as a singular, aleatory rupture, a certain play of forces taking morbid form within a series of natural conditions, such as climate, sanitary conditions, diet, and so on. And as we have already discussed, the task of a medicine of epidemics became that of identifying that "singular process" linking the causal knot of the constitution to the morbid form, a form that was held to be common to all who were afflicted, but singular in a particular place and at a particular time. ${ }^{28}$ The epidemic, then, was a complex, seemingly contradictory, event: as a "collective phenomenon" that has at its heart a "unique process," it called for a method of analysis and intervention suited to its peculiarities. The epidemic therefore required a new medical approach, one that would come to have far-reaching effects within the operation of what Foucault would later call the biopolitics of the population.

Constantly balancing the peculiar structure of a singular, yet collective, event, the emerging medicine of epidemics had to concern itself with two, seemingly contradictory, imperatives: to account for the singularity of the epidemic event while bringing to bear upon it a "multiple gaze" capable of accounting for the repetition of the event across an entire group of people. ${ }^{29}$ Accordingly, where the medicine of species had sought to establish a comprehensive pathological taxonomy within which could it could place a symptom, an illness, and so on, the analysis of constitutions and epidemics sought to "establish a network [réseau]" through the "play of series" that, by virtue of their intersection, enabled the reconstitution of the chain linking an epidemic constitution to its singular morbid form. ${ }^{30}$ The real work of the medicine of epidemics, that is, took place in that point of "systematic" intersection between various "series of information" that were "homogeneous" with respect to themselves but "different from one another," various series-such as observations concerning climate, quality of soil, \&c-that encompassed an "infinite grouping of separate [read, dispersed] events" whose aleatory combination allowed for the irruption of the "individual fact" of the morbid form. ${ }^{31}$ 
Here, then, the event of mass illness represents an "emergence within the fundamental structures," a novel figure in the practice of medicine as it conceived of itself during the classical epoch. ${ }^{32}$ And in response to this new figure of the epidemic event, an entirely new social model for the practice of medicine at the level of the collective would emerge. At the practical level, the response to these aleatory, singular events that ceaselessly threatened the health of entire groups of people took many different forms, all of which find their significance within the intervention of biopower at the level of the population and in the biopolitical effort to control and administer dangerous, aleatory events in the name of the protection of the social body.

\section{The Birth of State Medicine}

As a phenomenon different from that of an individual illness, an epidemic or endemic event called for new methods of intervention, methods that would emerge within the context of the definition of "a political status for medicine" and the constitution of "a medical consciousness" that, at the level of the state, would be charged with the "constant task" of "information, control, and constraint." In other words, here, in these passages of Birth of the Clinic, Foucault provides us with an early account of the emergence of what he would a decade later call a "politics of health" and a "social medicine," and which he would connect to the intervention of biopower upon the population. As he would show, the response to the phenomenon of mass illness, which posed a constant threat to the health of the social body, would eventually result in the widespread medicalization of society.

As Foucault explains, the nature of epidemic and endemic illnesses was such that a medical response to the threat they posed had, at least in part, to take the form of a "constant and constraining intervention," which is to say that there could be no effective medicine of epidemics that was not supported by a "police," in the sense of an authoritative body charged with the administration of the practice of medicine and the control of other aspects of life bearing directly upon the health of the social body, such as the location of mines and cemeteries, the incineration of cadavers, the regulation of slaughterhouses and tanneries, the eradication of conditions of life conducive to the irruption of epidemic events, and so on. In addition, this novel practice of medicine on a collective scale called for the elaboration of a new set of "health regulations," as well as the creation of a "corpus of health" tasked with observation and the collection of information and data to be disseminated throughout the social space. In this way, the medicine of epidemics represented a completely novel manner of practicing medicine and of conceiving of the status of illness in relation to society, entailing the "collective perception" of, and intervention upon, a massive, though singular, event. ${ }^{33}$ What appeared around this time, then, at the expense of an individuating medicine of species, was a practice of social medicine 
intended to fulfill a function of "totalization," with respect to both the diagnosis of the epidemic event and to its own proper point of intervention, which would now be the entirety of the social space. Beginning in the $18^{\text {th }}$ century, that which characterized the unity of the practice of medicine was this "open, infinite totalization," which had as its ultimate task the "clinical recording of a variable and infinite series of events" so that the control and management of these variable, aleatory events could then be assured in the name of the health of the population. ${ }^{34}$

In this task, the medicine of epidemics was to rely, as we have seen, upon a collective medical consciousness of all the observations made and data collected within a medicalized space now opened and enlarged to the dimensions of "a history, of a geography, of a state." ${ }^{35}$ This required, first and foremost, that the practice of medicine become centralized and subsequently effect the medicalization of the open social space as a whole. In other words, and in a process that we will examine in greater detail in the next part of this essay, the medical space had to be made to "coincide" with the social space or, rather, to "penetrate it completely," in a process that would take a variety of forms to be discussed later. ${ }^{36}$

Broadly, however, and in a formulation that would a decade later become typical of Foucault's account of biopower, we can say that this medicalization of the social space would both require and be effected through, first, the "generalized presence" of medical institutions and authorities, a presence that would lay the foundation for a "constant, mobile, and differentiated surveillance" at all times and in all corners of the social space. ${ }^{37}$ Thus, the classical epoch, in response to the danger posed by the epidemic event, came to witness the emergence of a novel social medicine that would, in its every action, greatly facilitate the extension of mechanisms and institutions of power over the entirety of the social space and social body, and do so in the name of their well-being.

Consequently, the locus of medical practice and knowledge ceased to be the pathological taxonomy of the species of illnesses and instead became a constant and "generalized medical consciousness" disseminated throughout the social space and "tied to each individual existence, but also to the collective life of the nation, always alert as to the indefinite domain where the danger [le mal] belies, under its diverse aspects, its great massive form." 38 With the emergence of a novel politics of health, the practice of medicine became inextricably tied to the "destinies of states," and was charged, along with other mechanisms of power, with instituting "in the life of men the figures of health, of virtue, and of happiness." ${ }^{39}$ This was achieved, at the level of the collective and in the context of the threat of the epidemic illness, through the constitution of a totalized, medicalized open space-a "homogeneous configuration" - in which an "exhaustive" and "permanent" knowledge of the "health of a population" could be established. ${ }^{40}$ During the $18^{\text {th }}$ century, the demands of a "political ideology" 
and those of a "medical technology" intersected, giving birth to a politics of health that would come to play an essential role in the biopolitics of the population elaborated within a regime of biopower in order to ensure the health and stability of the population. Exactly what form this politics of health took, as well as the exact nature of its relation to the population, will be the subject of the next section of this essay.

\section{The Medicalization of the Population}

As Guillaume le Blanc explains in La pensée Foucault, ${ }^{41}$ the new phenomenon of the study of mass endemic illnesses, of their length and causes, of morbidity, \&c, no longer solely at the individual level but also on the scale of the collective, resulted, as Foucault would observe in "Society Must Be Defended," in "the development of a medicine whose main function [would] now be that of public hygiene, with institutions to coordinate medical care, centralize power, and normalize knowledge." ${ }^{42}$ In other words, the classical epoch saw the widespread medicalization of the population, of the social space, as well as of the family and sexuality; at that time, the medicalization of the population was one of the chief measures in the biopolitics of a state for which the life (i.e., the biological health and wellbeing) of its population had become a major concern, and had therefore emerged as a point of application for various mechanisms of medical power. As we have just seen, moreover, even if Foucault waited until The Will to Knowledge to connect the increasing role of medical power in the lives of individuals and populations to his genealogy of biopower, it is a subject he had already explored in depth in Birth of the Clinic. And as we will now discuss, it is a topic he would revisit in a series of texts and lectures that set the stage for the work on power that was to come.

In a series of talks given in Brazil in 1974, Foucault returned to the question of the medicalization of the population and provided a deeper analysis of the emergence of a centralized politics of health during the classical epoch. Two lectures, in particular, contain the seeds of Foucault's later thought on biopolitics and biopower, and can therefore help us to understand better the crucial relation in Foucault's thought between biopower, population, and medicalization: the first lecture, entitled "Crisis of Medicine or Crisis of Anti-Medicine?" and never translated into English, addresses the question of the relation between the state and medicine, while setting the stage for the second lecture, "The Birth of Social Medicine," in which Foucault provides an analysis of the setup of medicalization that would become central to his later genealogy of biopower. ${ }^{43}$ In these important lectures, Foucault returns to the questions that had motivated part of his inquiry in Birth of the Clinic, but which he had not developed in greater depth. And in the process of returning to these questions, Foucault introduces for the first time the concepts of biohistory and biopolitics that would eventually become so prevalent in his later project. In Birth of the 
Clinic, Foucault had identified the problem of epidemics and endemic illness as one of the factors that had most contributed to the emergence of a novel form of medicine aimed at the homogenization of the social space and at the widespread medicalization of the population in the name of the health of the social body. Developing these themes further, Foucault would provide in "Crisis of Medicine or of Anti-Medicine?" and "The Birth of Social Medicine" a genealogy of this process of medicalization of the population, as well as a clearer basis on which to understand one of the most significant ways in which biopower came to exercise itself at the collective scale of the population.

Foucault proposes in "Crisis of Medicine or Crisis of Anti-Medicine that "we live under a regime for which one of the points of state intervention is the care of the body, the health of the body, the relation between sickness and health, etc." ${ }^{44}$ To be more specific, the $18^{\text {th }}$ century, as he had already discussed in Birth of the Clinic, saw not only a "vertiginous technological progress," but also a "political, economic, social, and juridical transformation of medicine," 45 a transformation whereby it is no longer the individual, or the individual illness, that is the focus of medical intervention, but a different object entirely; within modern medicine, he argues, "it is the entirety of the phenomenon of life that is (...) inserted into the field of action of medical intervention." ${ }^{46}$ In this analysis, certain elements echo much of Foucault's earlier work on medicine, while at the same time offering a glimpse of the genealogy of biopower that was to come in History of Sexuality, as well as his Collège de France lectures. Thus, Foucault notes, there appeared with this novel form of medical intervention a "new dimension of medical possibilities," which he calls "bio-history," in which medicine came to intervene upon the level of "life itself" and of its fundamental phenomena: "life and the history of man," in other words, are profoundly connected, such that human (that is, political) action can intervene upon the domain of life itself. ${ }^{47}$

Now, it is this intervention with which Foucault is concerned in these lectures, for it took the privileged form of what he calls an "indefinite medicalization": beginning in the classical epoch, medicine started to function "outside of its traditional field," as delineated by the patient's needs, the patient's pain, his or her symptoms, and so forth, and began to take on a social function it had not hitherto fulfilled. Anticipating the role that the concept of biopower would come to occupy within his genealogy, Foucault points out here that within this indefinite medicalization, medicine began to respond less to the needs of an individual patient and, rather, started "[imposing] itself upon the individual, whether sick or not, as an act of authority." 48 Moreover, the transformation of medicine of which Foucault provides a genealogy also saw a change in terms of the very object of medical transformation, from physical illness to objects like sexuality and health, both of which, it should be noted, would come to occupy crucial 
roles in ensuring the junction between biopower's disciplinary intervention upon the individual and its regulatory intervention upon the health of the population: as he proposes in this 1974 lecture on medicalization, "the authoritarian intervention of medicine in a domain of individual and collective existence that is each time more vast" is one of this new regime's most characteristic facts. ${ }^{49}$

Accordingly, this analysis of the indefinite medicalization of society, which he would describe in greater detail in his second lecture, leads Foucault to propose that today, "medicine possesses an authoritarian power," one with a normalizing function that reaches far beyond illness and the demands of a given patient. ${ }^{50}$ Now, what Foucault is describing here in terms of a biohistory is of course the very same process he would, in his work on biopower, connect to the birth during the 18th century of a biopolitics of health, whereby the domain of life itself emerged as a privileged object of state (in this case, medical) intervention. In this way, we can already see that his early work on medicalization would already anticipate much of his later analysis of biopower.

This is particularly evident in his analysis of the four processes that characterized the emergence of this novel medical power, namely, 1) the emergence of a medical authority whose decisions affect not only individuals, but entire villages, towns, and cities (that is, populations); 2 ) the emergence of an object of medical intervention distinct from illness (the air a population breathes, the water it drinks, its conditions of existence); 3) the introduction, in the form of the modern hospital, of an "apparatus of collective medicalization"; as well as, finally, 4) the creation of a centralized medical administration of the social body. Take together, these processes helped to establish a modern medicine that lacks any domain exterior to it. ${ }^{51}$ Thus, and in a statement that reveals just how central to his work this setup of medicalization had been and would continue to be, Foucault would conclude this first lecture with the following claim: within this indefinite medicalization of the population and the social space,

the preponderance given to pathology becomes a general form of the regulation of society. Today, medicine no longer has a field external to it. (...) One could affirm about the modern society in which we find ourselves that we live in 'open medical States' in which medicalization is without limits. ${ }^{52}$

As Foucault would later explain, this indefinite medicalization of society represents one of the most crucial developments in a regime of power whose chief concern became that of ensuring the well-being and health of entire populations. As problems like endemic and epidemic illnesses, as well as the space of the city, began to threaten not only individuals, but populations and, through them, the stability of the state, novel techniques and 
mechanisms were called upon to intervene both at the level of the individual and at the scale of the collective. Here, medicalization remains a privileged setup. And having merely broached the topic of medicalization in his first lecture, Foucault would devote his second lecture to the analysis of the emergence during the $18^{\text {th }}$ century of a social medicine tasked with intervening upon the social body as a whole.

Endeavoring to trace the development of the medical system since the $18^{\text {th }}$ century and to analyze the model guiding modern medical and hygienic practices, Foucault identifies, echoing his first lecture, two main avenues of inquiry, the first having to do with the establishment of a biohistory that would determine the effects at the biological level of the intervention of various medical institutions, the second having to do with an analysis of the $18^{\text {th }}$ century medicalization of the social body, whereby human existence, behaviors, and bodies came to be integrated into an increasingly tight "network [réseau] of medicalization." ${ }^{53}$ The purpose of Foucault's genealogy is therefore to study the development of medical institutions, particularly with respect to their effects on the lives of individuals and groups and in the context of their role in the medical investment of the population on the part of what he would later call biopower.

Starting from the question of whether the form of medicine that appeared during the $18^{\text {th }}$ century was an individual or collective form of medicine, Foucault, in accordance with what he had already proposed in Birth of the Clinic, asserts from the very beginning that "modern medicine is a social medicine whose foundation is a certain technology of the social body." ${ }^{54}$ That is not to say, of course, that the individual had no place in the novel form of medical practice that began to appear during the $18^{\text {th }}$ century, for as Foucault himself notes, society's control over its members is effected in part "in the body and with the body." Accordingly, the individual body became during this time a "biopolitical reality," even as medicine took on the form of a "biopolitical strategy." 55 Nevertheless, the form of medical practice that emerged during this time, even as it sometimes intervened upon the individual body, took the form first and foremost of a collective medicine, one whose development occurred in three moments.

The first moment in the emergence of a social medicine-and the one which Foucault had already discussed in Birth of the Clinic-saw the elaboration, during the classical epoch, of a state medicine, reflecting an increasing biopolitical concern with the promotion and management of the health of the collective. Thus, this epoch witnessed the birth of a form of medical practice dedicated to the "improvement of public health," a medical practice that was by necessity accompanied by a centralized "state medical police" that itself operated along four main axes: 1) a system of thorough and widespread observation and recording of phenomena tied to collective morbidity, such as epidemics and endemic illnesses; 2) the "normalization" not only of health practices and behaviors, but of medical practice and 
knowledge; 3) the creation throughout Europe of central administrative authorities, such as various professional medical societies, tasked with overseeing the activities of medical practitioners; and 4) the subsequent subordination of the practice of medicine, including the professional societies, to a generalized, centralized political authority. ${ }^{56}$

Taken together, these four developments in the practice of medicine during the $18^{\text {th }}$ century marked the advent of a novel medical practice concerned not just with the health of the individual patient, but with that of the social body as a whole, insofar as the health of the population was inextricably tied to the survival of the state. And in laying the foundation for the medical investment of society, this new practice of social medicine played an invaluable role in ensuring the junction between biopower's interventions at the level of the individual and those at the level of the collective.

Indeed, the novel social medicine put in place not only the conditions necessary for the control of aleatory events such as epidemics and endemic illnesses, but also those conditions necessary for the transformation of the individual into a medical subject whose behavior with respect to health and hygiene had a direct effect on the health of the population as a whole, and therefore on the survival of the state, and as a consequence had to be observed, regulated, and ultimately normalized. In this sense, the setup of medicalization that emerged during the classical epoch represents one of the privileged avenues through which the nascent technologies of biopower established and exerted their control over the individual, over the population, and ultimately over the field of life itself, with its attendant phenomena of variation and chance. This was achieved not only through the creation of a social medicine of the collective, but through a direct intervention upon the population's material conditions of existence.

Thus, as Foucault describes in "The Birth of Social Medicine," the second moment in the development of social medicine took the form of a thorough reorganization of the urban space, a process intended to eliminate those conditions of existence most conducive to the eruption of events of mass illness. For various reasons, the city-its structure, its spatial organization, its inhabitants-posed during the $17^{\text {th }}$ and $18^{\text {th }}$ centuries an increasing health problem. As Foucault points out, major cities between 1750 and 1780, prior to the great reorganization of the urban space, represented a "confused multitude of heterogeneous territories and of rival powers." ${ }^{57}$ Now, this dispersion of authority and of territories precluded any centralized power from exerting any sort of control over the city as a whole, with the consequence, in the context of the problem of the health of the population, that there existed no single set of laws and regulations administering the city's public health and medical practices. As a result, and in order to facilitate as much as possible the medicalization of the social space for which the newfound concern for the well-being of the population 
called, the problem of the unification and centralization of power over the city, as an environment inhabited by a population, had to be posed. Consequently, there appeared around the end of the $18^{\text {th }}$ century a need to "unify the city, to organize the urban body in a coherent and homogeneous manner," and thereby to administer the city through a single, unified authority; as one of the privileged avenues of control and investment of the population, the medicalization of society, and especially that of the city, required that the space in question be intervened upon and the power over it centralized and unified, so as to ensure the efficient administration of the life of the city and of its inhabitants. ${ }^{58}$

Central to the problem posed by the urban space around this time was the problem of the "urban population" and the "political-sanitary" danger it posed to the well-being of the social body. As a locus of social unrest, the city represented a threat to the stability of the state. But as a locus of infection, of contagion, and of epidemic, and as a result of the desultory health practices of its inhabitants and its filthy material conditions, the city represented an even greater danger, namely, that danger posed to the very health of its population. In order, then, to "dominate these medical and political phenomena," certain measures had to be put in place. Accordingly, the medicalization of the urban population and of its environment took as its model a practice and mechanism of intervention particularly well suited to the need for the establishment of constant surveillance and control over the city and its inhabitants, namely, the model of the quarantine. ${ }^{59}$

Developed in response to phenomena of mass illness, and particularly to outbreaks of the plague, the disciplinary model of the quarantine, taken as a model for the medical investment and administration of the population and its environment, provided several distinct advantages and called for practices that would eventually underlie the medicalization of the social body as a whole, such as, for instance, the confinement of families to their homes, the partitioning of the city into areas falling under the authority of a designated inspector who would observe, record, and report his findings to a higher authority, the inspection of homes and their subsequent disinfection, and so on. ${ }^{60}$ Though extreme, these practices nonetheless represented the "political-medical ideal" for the proper and efficient spatial and "sanitary organization" of the city and for the medical management of its population.

Indeed, where models of intervention developed in response to illnesses like leprosy had focused on the expulsion and exclusion of the afflicted from the population, the quarantine model relied on a medical and political power that sought

to position individuals in relation to one another [répartir les individus les uns à côté des autres], to isolate them, to individuate them, to monitor [surveiller] them one by one, 
to control their state of health, to verify whether they were still alive or whether they were dead and in this way to maintain society in a space that was compartmentalized, constantly under surveillance, and controlled by a register, as complete as possible, of all of the events that had occurred [évènements survenus]. ${ }^{61}$

As Foucault later explained in Security, Territory, Population, these techniques would come to be supplemented by an edifice of security that would be even better equipped to address problems of mass such as that of the epidemic. Nevertheless, understood in this manner, the quarantine provided a model for a medical intervention that had as its primary end the control and management of an entire population and the administration of its environment, which in turn allowed for the management of those aleatory events that most threatened the health of the population.

In its reorganization and regulation of the urban population's medical and hygienic practices, for instance through the increasing importance of the concept of salubriousness, its constant surveillance and control over the urban space, and its reorganization of the very arrangement of that space (in the form, for instance, of the relocation of mass cemeteries and slaughterhouses to the exterior of the city, or the reorganization of the city's streets in order to facilitate the circulation of the miasma believed to be responsible for outbreaks), urban social medicine established itself not only as a medicine of the individual person, body, or organism, but as a collective "medicine of the conditions of life of the environment of existence." ${ }^{62}$ And with the importance taken on by the problem of salubriousness and public health, the various authorities concerned with public hygiene and the population's medical practices-and, ultimately, the mechanisms of biopower-succeeded in establishing and subsequently exerting their control over that environment and its inhabitants, along with their attendant aleatory phenomena, in the name of their well-being, thereby facilitating and maintaining the perpetuation of the emerging mode of power.

\section{Conclusion}

In discussing biopower, to treat the setup of medicalization as distinct from those of sexuality and race is to run the risk of obscuring the fact that, for Foucault, each is inextricably connected to the others. Nevertheless, I have chosen here to focus on medicalization because, as I have already noted, it is the one concern that runs through the quasi-entirety of Foucault's œuvre. During the late 1970's, in texts like The Will to Knowledge and lecture courses like "Society Must Be Defended" and Security, Territory, Population, Foucault came to supplement his genealogy of modern disciplinary mechanisms with an account of a regime of power that ultimately took life, whether in the form of the individual body or that of the population and its various phenomena, as its domain of intervention. In this emergence of a 
regime of power exercised upon life at the level not just of the individual but also of the population, the medicalization of the individual, of the population, and of the social space represents the most significant biopolitical event. But an examination of his work on medicine reveals that as early as 1963, in Birth of the Clinic, Foucault was already concerned with some of the mechanisms and problems he would later place at the center of his work on biopower and biopolitics, specifically, the emergence during the classical epoch of a social medicine tasked with ensuring the biological wellbeing of entire populations through regulatory interventions upon their individual behaviors and their material conditions of existence, as well as the centralization and normalization of medical practice. Moreover, this examination of Foucault's work on medicine, and specifically of the 1974 Brazilian lectures, reveals that even before he had arrived at a conception of biopower, concepts like those of biohistory and biopolitics had already begun to play central roles in his understanding of power.

In a 1973 interview, Foucault proposed that "today, the world is evolving toward a hospital model, and the government has taken on a therapeutic function. The function of those in charge [namely, doctors, psychologists, psychiatrists, criminologists] is to adapt individuals to the process of development, in accordance with a veritable social orthopedics." ${ }^{\prime 63}$ A year later, he would echo this sentiment, proposing, as we have already seen, that medicine today has no field that is external to it: we inhabit, according to Foucault, open medical States in which every behavior, every space, every vital process is susceptible to medicalization, pathologization, regulation, administration, and normalization. As Guillaume le Blanc notes, "the government of life finds, in the exercise of biopower, its true birth." ${ }^{64}$ Now, if we want to understand Foucault's genealogy of biopower, we must be sure to understand the setup of medicalization, insofar as it represents a privileged means through which the junction between the technology/politics of the individual body and the technology/politics of the population was assured. And as I have tried to show here, understanding the setup of medicalization requires that we look not only to Foucault's later writings on biopower proper, but also to the work on medicine that occupies such a significant place in his project, for it is in that work that the seeds of Foucault's genealogy of biohistory, biopolitics, and, ultimately, biopower can be found.

${ }^{1}$ The word dispositif occupies in Foucault's thought a significant and complex role. Difficult to translate, the word has traditionally been translated into English as "apparatus," "device," or "deployment," terms that fail, I think, to convey what Foucault meant by the concept. In a 1977 panel discussion concerning The Will to Knowledge, the first volume of his History of Sexuality, Foucault would define a dispositif in the following manner: 1) as a heterogeneous 
group of discourses, institutions, spatial arrangements, laws, administrative measures, scientific statements, philosophical and moral propositions, and so forth; 2) as the relation between those heterogeneous elements; and 3) as a strategic "formation" that, at a given historical moment, emerges in response to a certain urgency or problem. Throughout this essay, I have chosen to translate dispositif as "setup." Cf. Michel Foucault, "Le jeu de Michel Foucault," in Dits et écrits, III, 1976-1979 (Paris: Gallimard, coll. Bibliothèque des sciences humaines, 1994 [1977]), 299; a problematic translation of this panel session can be found in Power/Knowledge under the title "The Confession of the Flesh," ed. Colin Gordon, (New York, NY: Pantheon Books, 1980), 194-228.

${ }^{2}$ Guillaume le Blanc, La pensée Foucault (Paris: Ellipses, 2006), 154.

${ }^{3}$ Foucault mentions medicalization several times in The Will to Knowledge, but always as if this medicalization of human life had never been more than an almost secondary aspect of the setup of sexuality. See, for instance, p. 90/67, where Foucault discusses the "medicalization of the confession," or p. 167/126, where he classifies medicalization amongst those techniques of control that were put in place during the 19th century to monitor the body and its sexuality.

4 See Michel Foucault, "Il faut défendre la société” (Paris: Seuil/Gallimard, 1997), 213-235; English translation by David Macey as "Society Must Be Defended" (New York: Picador, 2003), 239-263.

5 Michel Foucault, Histoire de la sexualité, volume 1, La volonté de savoir (Paris, France: Gallimard, coll. Bibliothèque des histoires, 1976), 180; English translation by Robert Hurley as History of Sexuality, Volume 1, An Introduction (New York, NY: Vintage Books, 1978), 137, translation modified. Throughout this essay, I refer to this text as The Will to Knowledge.

${ }^{6}$ Foucault, The Will to Knowledge, 180/137 (translation modified).

${ }^{7}$ Foucault, The Will to Knowledge, 188/143 (translation modified).

${ }^{8}$ Foucault, The Will to Knowledge, 182-183/139.

9 Michel Foucault, Sécurité, Territoire, Population (Paris: Seuil/Gallimard, 2004), 66; English translation by Graham Burchell as Security, Territory, Population (New York, NY: Palgrave McMillan, 2007), 66.

${ }^{10}$ Foucault, The Will to Knowledge, 35/25.

${ }^{11}$ Foucault, The Will to Knowledge, 35/25 (translation modified).

${ }^{12}$ Foucault, The Will to Knowledge, 36-37/25-26.

${ }^{13}$ Le Blanc, La pensée Foucault, 158-159. As le Blanc explains, "if the disciplines exist only to the extent that they intensify production [and] the behaviors that draw from the body's forces, biopower, by concentrating on this force (...) beyond its movement of individualization, undoes the disciplinary drama that is extenuation, fatigue, and death." In other words, in its administration and regulation of life, in its maximization of the health of the population, biopower addresses the one problem to which the disciplines could propose no solution: that of the fatigue and death of the productive individual.

14 Here, we could cite, for instance, the importance of the cleavage between the normal and the pathological, the role of psychiatry, the theory of degeneration, the family, the elimination of the incorrigible individual, the constitution of the monster and the pervert, 
etc, all of which, in one form or another, involve the mutually-reinforcing setups of sexuality, race, and medicalization. Moreover, though more needs to be said about Foucault's reference to race in the Abnormal and "Society Must Be Defended" lectures, we should also add that he is referring in those lectures to the biological discourse of race that appeared during the $19^{\text {th }}$ century in the work of psychiatrists like B.A. Morel and of criminologists like Cesare Lombroso, a discourse of race that was grounded less, if at all, in what one could call "ethnic" racism and which took the form, rather, of a biologization of the abnormal.

Mauro Bertani, "Sur la généalogie du bio-pouvoir," in Lectures de "ll faut défendre la société," ed. Jean-Claude Zancarini (Lyon: ENS Editions, 2001), 15.

Michel Foucault, Naissance de la clinique (Paris: Presses Universitaires de France, coll. Galien, 1972). The publishing history of this text is a singular one, and one that calls for an explanation. First published in 1963 by the PUF in Georges Canguilhem's Galien collection, Naissance de la clinique underwent a fair amount of revision upon its republication in 1972, mainly in order to eliminate what Foucault had come to consider as overly-structuralist language from the original edition. Today, the version of the text most widely available is of course the latter revision, rather than the original 1963 edition. To complicate matters further, A. M. Sheridan Smith, in his translation, inexplicably decided to translate an arbitrary combination of both editions, with no mention or explanation as to which passages come from which edition. For this reason, the English translation of Birth of the Clinic is, at best, useless and, at worst, irresponsibly misleading. I therefore provide my own translations of the passages cited from Naissance de la clinique. The citations I provide are from the 1972 revision (all subsequent editions in the Quadrige collection are identical to this one), making note of those cases where the passage I cite differs significantly from the 1963 edition. It is important to note that in the passages I will cite here, only one differs significantly across the two versions of the text, indicating that Foucault was already in 1963 concerned with what he would later refer to as "medicalization."

${ }^{17}$ Foucault, Naissance de la clinique, 16.

${ }^{18}$ Foucault, Naissance de la clinique, 16.

${ }^{19}$ Foucault, Naissance de la clinique, 17.

${ }^{20}$ Foucault, Naissance de la clinique, 18.

${ }^{21}$ Foucault, Naissance de la clinique, 18.

22 Foucault, Naissance de la clinique, 18-19.

${ }^{23}$ Foucault, Naissance de la clinique, 21. On page 21 of the 1963 edition of Naissance de la clinique, Foucault uses the expression "a marginal fortune," rather than "singular destiny." Replacing the former with the latter in the 1972 reedition makes it clearer that the concepts of "endemic illness" and "epidemic," while playing a minor role in the dominant medicine of species, would come to occupy a central position in the emerging medicine of the collective.

${ }^{24}$ Foucault, Naissance de la clinique, 21.

${ }^{25}$ Foucault, Naissance de la clinique, 22.

${ }^{26}$ Foucault, Naissance de la clinique, 23.

${ }^{27}$ Foucault, Naissance de la clinique, 21. 
${ }^{28}$ Foucault, Naissance de la clinique, 23.

${ }^{29}$ Foucault, Naissance de la clinique, 24.

${ }^{30}$ Foucault, Naissance de la clinique, 29.

${ }^{31}$ Foucault, Naissance de la clinique, 30.

32 Foucault, Naissance de la clinique, 28.

33 Foucault, Naissance de la clinique, 25.

${ }^{34}$ Foucault, Naissance de la clinique, 28.

${ }^{35}$ Foucault, Naissance de la clinique, 29.

${ }^{36}$ Foucault, Naissance de la clinique, 30.

${ }^{37}$ Foucault, Naissance de la clinique, 31.

${ }^{38}$ Foucault, Naissance de la clinique, 31.

${ }^{39}$ Foucault, Naissance de la clinique, 34.

${ }^{40}$ Foucault, Naissance de la clinique, 37.

${ }^{41}$ Le Blanc, La pensée Foucault, 159.

42 Foucault, "Il faut défendre la société," 217; "Society Must Be Defended," 244.

43 There was also a third lecture, entitled "L'incorporation de l'hôpital dans la technique moderne." Cf. Dits et écrits, volume III, 1976-1979 (Paris: Gallimard, coll. Bibliothèque des Sciences Humaines, 1994), 508-521.

44 Michel Foucault, "Crise de la médicine ou crise de l'antimédicine?," in Dits et écrits, volume III, 1976-1979 (Paris: Gallimard, coll. Bibliothèque des Sciences Humaines, 1994), 43. This text has not yet been translated into English.

${ }^{45}$ Foucault, "Crise de la médicine ou crise de l'antimédicine?," 43.

${ }^{46}$ Foucault, "Crise de la médicine ou crise de l'antimédicine?," 48.

${ }^{47}$ Foucault, "Crise de la médicine ou crise de l'antimédicine?," 48.

${ }^{48}$ Foucault, "Crise de la médicine ou crise de l'antimédicine?," 48-49. As examples, Foucault cites the practice of mandating a medical exam prior to hiring an individual, as well as mandating a psychiatric evaluation of an individual suspected of having committed a crime.

${ }^{49}$ Foucault, “Crise de la médicine ou crise de l'antimédicine?," 50.

${ }^{50}$ Foucault, “Crise de la médicine ou crise de l'antimédicine?," 50.

${ }^{51}$ Foucault, "Crise de la médicine ou crise de l'antimédicine?," 51.

52 Foucault, "Crise de la médicine ou crise de l'antimédicine?," 53.

53 Michel Foucault, "Naissance de la médicine sociale," in Dits et écrits, volume III, 1976-1979 (Paris: Gallimard, coll. Bibliothèque des Sciences Humaines, 1994), 208; English translation by Robert Hurley as "The Birth of Social Medicine," in Essential Works of Michel Foucault, Volume 3, Power, eds. Robert Hurley and Paul Rabinow (New York, NY: The New Press, 2001), 135. 
${ }^{54}$ Foucault, “Naissance de la médicine sociale," 209/136 (translation modified).

\section{5}

Foucault, "Naissance de la médicine sociale," 210/137.

${ }^{56}$ Foucault, "Naissance de la médicine sociale," 213-214/140-141.

${ }^{57}$ Foucault, “Naissance de la médicine sociale," 215/143 (translation modified).

${ }^{58}$ Foucault, "Naissance de la médicine sociale," 215/143.

${ }^{59}$ Foucault, "Naissance de la médicine sociale," 217/144-145.

${ }^{60}$ Foucault, "Naissance de la médicine sociale," 217-218/145.

${ }^{61}$ Foucault, "Naissance de la médicine sociale," 218/146 (translation modified).

${ }^{62}$ Foucault, “Naissance de la médicine sociale," 222/150 (translation modified).

${ }^{63}$ Michel Foucault, "Le monde est un grand asile," in Dits et écrits, volume II, 1970-1975 (Paris: Gallimard, coll. Bibliothèque des Sciences Humaines, 1994), 433. There exists no English translation of this text.

${ }^{64}$ Le Blanc, La pensée Foucault, 158. 